\title{
Research on the Status of English Teaching of the Postgraduate Students in the Chinese Agricultural Universities
}

\author{
Jingyuan Xie \\ College of Humanities \\ Tianjin Agricultural University \\ Tianjin, China
}

\begin{abstract}
The English level of the non-English major graduate students in the agricultural university is relatively low for many years in China. How to improve the students' English basic level in their postgraduate stage in the limited time is should be studied for. In this paper, some strategies to improve their language ability are put forward.
\end{abstract}

Keywords-English teaching; Agricultural university; Postgraduate

\section{INTRODUCTION}

The English level of the different professional graduate students in Agriculture universities is relatively low; such a big problem has been affecting the English teaching in school. According to related survey data, the entrance score of English is also low compared with the other professional comprehensive universities. And the students' individual English levels are uneven and the difference is obvious, and this situation has been continuing for many years. Investigation shows that the source of agricultural college students is relatively narrow. The English level of the undergraduate students is not good their language base is weak. The situation has restricted the system construction of English course and its development. If you want to change the results, you should explore more effective new strategies of teaching and learning in the postgraduate stage.

\section{INVESTIGATION AND ANALYSIS OF PRESENT}

\section{A. English Teaching Goal of the Graduate}

The aims of their English course of the graduate students in the agricultural colleges are: 1 . improving the students' ability on English reading and translation skills about the academic articles; 2 . improving the students' ability of the thesis retrieval and the writing skills on the English academic paper; 3 . improving the students' ability of the communication and cooperation skills with foreign experts; 4 . improving the ability of the agricultural technology talents with the English synthetic language.

The cultivation to the non-English major graduate students in agricultural colleges is to make them become the talents in the field of agricultural science and technology. Under the globalization trend, English reading and translation ability is crucially important for the agricultural scientific researchers who want to communicate with foreign experts fluently and to understand the foreign expert lectures. The ability of reading English literature related to the agricultural technology knowledge without barrier and of understanding the translation correctly is more important.

\section{B. The Admission Status Analysis}

The sources of the agricultural college students are narrow for a long time. In the college admissions phase, the requirements for students' English are not very high in the agricultural colleges and the agricultural major in the comprehensive university; the difference between the other colleges and universities in the graduate stage is obvious. The following table is about English second-round exam qualification of fractional line of postgraduate of A-class areas in China in recent years, it shows that the English score has always been in a low level "Table I".

TABLE I. 2010-2016 MASTER’s AdMISSION IN CLASS A, FrACTIONAL LINE OF SECOND-ROUND EXAM ONLY BRANCH (ENGLISH)

\begin{tabular}{ccccccccccc}
\hline Test subjects & $\mathbf{0 6}$ & $\mathbf{0 7}$ & $\mathbf{0 8}$ & $\mathbf{0 9}$ & $\mathbf{1 0}$ & $\mathbf{1 1}$ & $\mathbf{1 3}$ & $\mathbf{1 4}$ & $\mathbf{1 5}$ & $\mathbf{1 6}$ \\
\hline economics & 56 & 53 & 54 & 47 & 46 & 55 & 49 & 45 & 45 & 45 \\
philosophy & 46 & 46 & 41 & 37 & 36 & 40 & 42 & 44 & 42 & 45 \\
pedagogy & 53 & 50 & 49 & 42 & 41 & 40 & 40 & 42 & 44 & 45 \\
law & 55 & 53 & 53 & 46 & 43 & 45 & 42 & 44 & 42 & 45 \\
\hline history & 48 & 41 & 39 & 40 & 36 & 55 & 40 & 42 & 42 & 44 \\
literature & 57 & 55 & 57 & 51 & 50 & 55 & 54 & 55 & 52 & 53 \\
\hline engineering & 45 & 41 & 44 & 37 & 36 & 40 & 40 & 38 & 38 & 36 \\
science & 46 & 49 & 47 & 38 & 37 & 45 & 39 & 38 & 36 & 39 \\
medicine & 48 & 44 & 44 & 39 & 37 & 55 & 38 & 38 & 39 & 41 \\
\hline agriculture & 39 & 40 & 39 & 32 & 32 & 40 & 33 & 34 & 34 & 34 \\
management & 54 & 54 & 54 & 47 & 46 & 40 & 51 & 48 & 46 & 45 \\
military & 46 & 46 & 49 & 48 & 42 & 45 & 40 & 38 & 39 & 38 \\
arts & 47 & 45 & 45 & 42 & 32 & 40 & 34 & 34 & 34 & 34 \\
sports & 47 & 45 & 42 & 39 & 36 & 55 & 34 & 34 & 34 & 34 \\
\hline
\end{tabular}

The programs in the graduate period involved agriculture horticulture, animal science and fisheries, they all belong to agronomy science and they are the main body classes in the agricultural colleges and universities. The requirement to the examinee's English for the four disciplines is not high; the scores line is lower than other comprehensive colleges and universities. And this is a reality. 


\section{The Analysis on the Student's Problem}

The low English level of the graduate students in agricultural colleges and universities mainly displays in the following aspects. Firstly, the weak skills in listening and speaking are very serious because the large rural students are lack of the basic training in middle school. They have less listening materials in their basic education stage and their interests are lost in their English study gradually. It has also caused many problems in the follow-up study. Secondly, the quantity of English vocabulary is not enough, especially the vocabulary about some professions major. It influenced the students' understanding on literature seriously. The obstacles from literature details will influence the students' interests in their reading. Thirdly, because the understanding ability of the syntax, especially the analysis ability to the structure of long sentence is not strong, the students would not get the real information of the articles. While the syntax disorders of the complex sentence and complex sentence can also block the students' understanding about the literature itself. And furthermore, because of the lack knowledge about the English discourse and the unclear logical thinking, the deep expression of literature would not be well analyzed, inducted, reasoned and evaluated by the students.

According to the training goal of English teaching about the graduate students, to explore the more suitable new strategy is imperative for us in order to solve the above issues.

\section{The CurRiculum AND Teaching Methods}

\section{A. The Theoretical Basis of the Curriculum}

Traditionally, all the core courses in the college focus on the two major themes: listening-speaking and reading-writing, which are the processes of the input and output of language. Input refers to the process that the language learners heard or read within the category of language teaching. American linguist SD. Krashen put forward the famous second language acquisition theory in the early 1980s. In his theory, the comprehensible input is the only way of the second language acquisition, and SD. Krashen thinks that the ideal language input should conform to the "I +1 " formula (I for the learners" current levels, 1for the little higher level more than I). The main task of teaching is to provide sufficient and comprehensible input training, which should not only include the students' mastered language knowledge-'I', but also include the new language knowledge-' 1 '. The gap between "I" and "I +1 " is the learning motivation of the learners. The difficulties of the materials in the language input should be slightly higher than that of learners' current levels. In order to get new input language materials, the learners of the ' $I+1$ ' formula will focus the previous knowledge or use the context to make the right judgment. The learners can understand the "difficult composition" in language input through study hard, and then get the great achievements in language learning.

Output refers to the process that the speaking-writing skills are used by the learners in the language teaching category. And comprehensible output training can promote the ability of the second language acquisition from three respects, namely its three functions: (1) Noticing/triggering function: the second language learners can realize some problems in their own language system through language output, and then to trigger the consolidation of the mastered language knowledge and the cognitive processes to obtain the new language knowledge. (2) Hypothesis testing function: language output can be as validating their formation in the process of learning language form and language structure by the second lnguage learners. (3) Metalinguistic function: when the learners reconsider their own target language usage, the output would show meta language features.

The postgraduate English course is based on this theory, including listening, speaking (by foreign teachers), and literature reading, writing and translating. It covers all links of the input and output. But after more than six years of teaching practice, the improvement of students' English comprehensive ability is not ideal enough, especially for their ability on literature reading and translation. To explore more effective strategies and methods and to improve the students' ability of reading and translating are the problems that we should seriously consider.

\section{B. Textbook and Teaching Methods}

Now we take the Literature Reading and Translation as textbook, which is edited by $\mathrm{Hu}$ Gengshen. It belongs to the 21st century key program lists of the Higher Education Press. This textbook is used in many domestic colleges and universities at the stage of graduate and doctoral students. Its purpose is to help the students to understand and master the basic content of professional literature and the usage of the language features, as well as the knowledge of the information retrieval in order to improve the students' ability of reading and translating skills about different kinds of professional literature. The editors of the textbook protruded some features of the high teaching level of English, and the graduate students' strong academic characteristics on their improving stage. The teachers focused on the cultivating the students practical ability to communicate with international personnel in English. The progressiveness, practicability, pertinence and guidance from the reality are paid attention to in the teaching materials. The materials are full of the accurate examples and the standardized language. Textbooks are divided into 15 chapters, including two types: industrial business and academic exchanges. Some reading materials, exemplification, translation skills and a great of practices are attached to the illustration. It is the comprehensive quality one among the similar teaching materials.

We benefit from this textbook for many years. It makes the students learn all aspects of the literature reading materials, acquire the basic information about the literature class, enlarge their vocabulary and basic knowledge. The teachers make lectures while the students participate. The period and final assessment are together taken to evaluate the teaching tasks.

\section{The Problems about Textbook}

Although the teaching materials we used are relatively excellent among the similar ones, it really belongs to the advanced English teaching material at the stage of the graduate. The English level of the graduate students in the agronomical colleges and universities is usually low. We should do some positive and effective work to remedy our shortages and disadvantages, and the students' ability of literature reading 
and translation could be improved. So to supplement the knowledge at the basic stage quickly is our prior work. The ability of literature reading and translation is the most important ability in the graduate stage; it plays an important role in the students' subsequent development and ascension. On the basis of the experience of the previous teaching and learning, to explore some new teaching and learning methods is very necessary and meaningful.

\section{THE NEW STRATEGIES DisCUSSION}

The English learning in graduate stage should cast off the pitfalls of exam-oriented education. The written test scores were taken into account in the past only. We just pay attention to memorizing words and grammatical syntax mechanically and to broadcast the listening material in class. Such kind exam-oriented education is to run counter to the purpose of English education which put the English learning as a scientific research and communication tools at graduate level. On the basis of strengthening the ability of listening and speaking skills, the training of the ability of literature reading and translation has adopted some effective new strategies.

\section{A. The Combination Module of Classroom Teaching and Extra Curricular Practice}

In class, the teachers should focus on analyzing the characteristics, the context and the vocabulary usage of the literature materials about the technology articles to make the students grasp the basic reading skills and translation methods. Another teacher's task is to explain the characteristics of science and technology vocabulary about its polysemy and the part of speech to make the students realize the transformation of the old words in the new context, and also let them know how the new words are created and its characteristics and its significance and so on. The teachers should analyze the teaching materials in English in class to improve their literature reading and translation skills, to ask the students to do PPT ahead of schedule, and to make lecture in class in English to practice both English speaking ability and the cooperation ability of the students.

S. Krashen (1981) argues that the individual learning is in a certain historical, social and cultural background. The society can play an important role in supporting and promoting development for the individual learning. Constructivism Theory should be made full use of outside the classroom. The students should be taken as the learned-center. To arrange the multiple learning tasks for the students including reading a great deal of this professional English materials, paper, and information and so on is necessary. By means of the network multimedia application, a wide varied form of language input will be carried while to increase extracurricular translation tasks at the same time. To guide the student's individualized and professional learning in English is necessary. The group inspection and the cooperation marking are as the methods of periodic evaluation in order to promote the students' sense of urgency, to increase the reading quantity and to improve their reading comprehension skills. The translation level is also correspondingly improved at the same time.

\section{B. The Combinations of the Literature Reading Training and Translation Exercises}

The students are too lack of researching spirit to spent time and energy on English reading now because their thoughts are just to complete the basic learning tasks to get a diploma degree before. Some of them give up reading English on the latest research literature, international authoritative journals and related research works in the field of the dynamic capabilities, which seriously restrict the improvement of their professional career. So we also establish to contact with student's mentor and mobilize them to give their students a lot of professional English reading tasks in order to improve their reading ability on professional English gradually.

The translation skills are based on the certain language ability and knowledge. We pay more attention to practice in addition to imparting skills and basic knowledge in our translation courses. And then the students must complete the task which is relevant with the professional literature translation practice. At the graduate level, setting priority research ideas in the English teaching to the students than the English teaching itself is more important. To cultivate their confidence and interest from the simple tasks to difficulty ones can also improve the sense of achievement and interest for their English translation ability.

\section{The Combinations of the Basic Leak Repairing and Advanced Reading Translation}

The English level of the graduate students in the agricultural university is relatively poor. Although the advanced reading and translation can help improve the research work in their own professional field, the problem of weak foundation is the restriction to the improvement. We have no more time to do leak repairing only, but to rise to the high level cannot be achieved without a good foundation.

After studied their situation, our teacher team adopted the combination principle of both leak-repairing and improving positively. Firstly, to solve the problem of their subjective thought and to let the students fully realize the importance of English learning on its subsequent development; Secondly, to correct their learning attitude and to improve their enthusiasm to learn English; Thirdly, to make reasonable teaching plan and to arrange a lot of basic learning tasks in their spare time; fourthly, to put some part of the content as the summative evaluation to be the attractive way for students learning. While at the same time, we also arrange some improving trainings in the classroom and extracurricular training module.

\section{CONCLUSION}

The development of modern science and technology demands for interdisciplinary talents who understand professional English is more and more becoming a trend. English is not just a language tool, it is the indispensable basic ability based on the professional development to improve quality education. Both teachers and graduate students will realize the importance of English. Modern agricultural development needs the talents who have the more practical application ability of agricultural technology. The improvement of the professional and technical skills will not become true without the international exchanges and 
cooperation, English reading and translation ability is the foundation and the key of its development.

\section{REFERENCES}

[1] Bai, J. P., and He, J. Q. (2015). (eds.) Analysis on Improving Professional Ability of English Teaching Mode of the Graduate Student in Agriculture Universities. Journal of TianShui Normal College, 35(5), 106-109.

[2] Chen, Y. (2015). To Explore and Practice on English Curriculum Reform of Graduate Education Teaching Methods in Agricultural Colleges. Agricultural Colleges Academic Study. 147(4), 207-207.

[3] Krashen, S. (1981). Second Language Acquisition and Second Language Learning. Oxford Pergamon.

[4] Swain, M. and Bowers, W. (1991). (eds.) Applied Linguistics and English Teaching. Macmillan Publishers Limited.

[5] Zhang, R. B. and Pan, S. M. (2012). (eds.) Entrance English Analysis on the Graduate Students in Agricultural University. Journal of Higher Agricultural Education, 56(8),82-85.

[6] Zhao, Y. J. and Pan, S. M. (2012). (eds.) Present Situation Investigation and Analysis on Agricultural College Graduate English Teaching. Agricultural Education Research, 71(1), 26-29.

[7] http://yz.chsi.com.cn/ (http://www.eol.cn/). 